\title{
Biological Control of Cyclamen Soilborne Diseases by Serratia marcescens Strain B2
}

\author{
N. Someya and N. Kataoka, Faculty of Agriculture, Ibaraki University, Ami-machi, Ibaraki 300-0393, Japan; T. \\ Komagata, Ibaraki Horticultural Research Institute, Minori-machi, Ibaraki 319-02, Japan; K. Hirayae, Kyushu Na- \\ tional Agricultural Experiment Station, Nishigoshi, Kumamoto 861-11, Japan; T. Hibi, Faculty of Agriculture, The \\ University of Tokyo, Bunkyo-ku, Tokyo 113, Japan; and K. Akutsu, Faculty of Agriculture, Ibaraki University, \\ Ami-machi, Ibaraki 300-03, Japan
}

\begin{abstract}
Someya, N., Kataoka, N., Komagata, T., Hirayae, K., Hibi, T., and Akutsu, K. 2000. Biological control of cyclamen soilborne diseases by Serratia marcescens strain B2. Plant Dis. 84:334-340.

Cyclamen plants were treated with a highly chitinolytic bacterium, Serratia marcescens strain B2, and then challenge inoculated with Rhizoctonia solani sclerotia or Fusarium oxysporum $\mathrm{f}$. sp. cyclaminis conidia. The bacterium suppressed these fungal diseases of cyclamen plants, especially the damping off caused by $R$. solani, in a greenhouse. Strain B2 survived at approximately $10^{6}$ to $10^{7} \mathrm{CFU} / \mathrm{g}$ in soil for 4 months after the initial application under greenhouse conditions. Chitinolytic enzymes and antifungal low-molecular-weight compounds were present in filtrates of $S$. marcescens B2, which suppressed germination of $R$. solani sclerotia in vitro.
\end{abstract}

Additional keywords: antifungal low-molecular-weight compounds, chitinolytic enzymes, Fusarium oxysporum f. sp. cyclaminis, Rhizoctonia solani

Damping off, caused by Rhizoctonia solani, and Fusarium wilt, caused by Fusarium oxysporum f. sp. cyclaminis, are the most common soilborne diseases of cyclamen plants in greenhouses. Most cyclamen cultivars are highly susceptible to these fungal pathogens. Typically, these soilborne diseases are controlled by repeated applications of fungicides; however, repeated applications of broad-spectrum or persistent fungicides may result in soil contamination, fungicide resistance, or harmful effects to nontarget organisms. Thus, biological control is an attractive alternative strategy for the control of cyclamen diseases.

We recently reported that a highly chitinolytic bacterium, Serratia marcescens B2, isolated from tomato phylloplane, suppressed the growth of Botrytis spp. in vitro (1) and controlled broad bean chocolate spot, caused by $B$. fabae, in a growth chamber $(4,21)$ and cyclamen gray mold, caused by $B$. cinerea, in a greenhouse (5). $S$. marcescens B2 suppressed growth and infection of the fungicide-resistant isolates as effectively as the fungicide-sensitive

Corresponding author: K. Akutsu

E-mail: akutsu@agr.ibaraki.ac.jp

This work was supported in part by a grant in aid for scientific research from the Ministry of Education, Science and Culture of Japan (06660046).

Accepted for publication 30 November 1999.

Publication no. D-2000-0124-04R

(C) 2000 The American Phytopathological Society isolates, both in vitro and in vivo $(1,4,5,21)$. Also, the isolate persisted on leaf discs placed at the base of cyclamen plants and on the phylloplane under humid conditions (5). S. marcescens is a ubiquitous organism in water, soil, and food (3); thus, the bacterium may survive well in a greenhouse environment.

Our study was initiated to control cyclamen soilborne pathogens $R$. solani and F. oxysporum f. sp. cyclaminis with $S$. marcescens B2 under greenhouse conditions. Although some soilborne diseases develop in cyclamen plants throughout the cultivation period, no effective controls for them have been developed. Efficacious control methods are urgently needed for commercial growers. Our objectives were to establish an efficient strategy for biocontrol of soilborne diseases in cyclamen plants, and evaluate integrated control of $R$. solani and $F$. oxysporum f. sp. cyclaminis with $S$. marcescens B2.

\section{MATERIALS AND METHODS}

Inoculum production. $S$. marcescens strain B2, isolated from the phylloplane of tomato plants growing in a field near Kyusyu University, Japan, was stored as freeze-dried samples at Ibaraki University. The bacterium was routinely cultured at $28^{\circ} \mathrm{C}$ on chitin-amended Luria broth (LB) agar medium (LBCA; $10 \mathrm{~g}$ of tryptone, $5 \mathrm{~g}$ of $\mathrm{NaCl}, 5 \mathrm{~g}$ of yeast extract, $1.8 \mathrm{~g}$ of colloidal chitin, and $15 \mathrm{~g}$ of Bacto-agar [Difco Laboratories, Detroit] in 1 liter of distilled water; 1). For applications, the bacteria, which were incubated in liquid LB medium at $28^{\circ} \mathrm{C}$ on a reciprocal shaker (125 strokes/min) for $48 \mathrm{~h}$, were collected by centrifugation at $10,000 \mathrm{rpm}$ for $10 \mathrm{~min}$, and diluted with sterile water to approximately $1 \times 10^{9} \mathrm{CFU} / \mathrm{ml}$. $R$. solani AG-4 was obtained from the Institute for Fermentation (IFO, Osaka, Japan). To produce sclerotia, the fungus was grown on potato sucrose agar (PSA) medium at $25^{\circ} \mathrm{C}$ in the dark for 2 to 3 weeks. The sclerotia (approximately $3 \mathrm{~mm}$ in diameter) were incubated in potato sucrose (PS) liquid medium at $25^{\circ} \mathrm{C}$ for $24 \mathrm{~h}$ on a reciprocal shaker (125 strokes/min) before use as inoculum.

F. oxysporum f. sp. cyclaminis IHF-1 was isolated from Fusarium wilt-diseased cyclamen plants in Ibaraki Horticultural Research Institute greenhouses (Minorimachi, Ibaraki, Japan). To produce the inoculum, the fungus was incubated on PSA at $25^{\circ} \mathrm{C}$ in the dark for 4 days. Mycelial discs (5 $\mathrm{mm}$ in diameter), cut with a cork borer from the colony, were cultured in PS liquid medium at $25^{\circ} \mathrm{C}$ for 5 days on a reciprocal shaker (140 strokes/min). The culture was centrifuged at 5,000 rpm for 5 min and the pellet resuspended in sterile distilled water, then passed through four layers of sterile tissue paper to remove mycelial fragments. The conidial suspension was adjusted to a concentration of approximately $1 \times 10^{6}$ conidia/ml for use as inoculum.

Plant materials. Cyclamen (Cyclamen persicum Miller) cv. Pias was used in this study. Seed was sown on artificial soil (Metro-Mix 360, Scotts-Sierra Horticultural Products Co., Marysville, $\mathrm{OH}$ ) and kept in the dark for 4 weeks at $25^{\circ} \mathrm{C}$ with high moisture. Seedlings grown for 2 to 4 weeks under greenhouse conditions were used in experiments with $R$. solani. Plants grown for approximately 5 months in pots $(15 \mathrm{~cm}$ in diameter and $10 \mathrm{~cm}$ tall) under greenhouse conditions were used in experiments with $F$. oxysporum f. sp. cyclaminis.

In vitro antifungal activity assay. Four paper discs ( $7 \mathrm{~mm}$ in diameter) inoculated with a 20 - $\mu$ l suspension (approximately $10^{9}$ $\mathrm{CFU} / \mathrm{ml}$ ) of $S$. marcescens strain B2 were placed on LB agar (LBA), LBCA, PSA, and chitin-amended potato sucrose agar (PSCA) media on Petri dishes $(90 \mathrm{~mm}$ in diameter). After incubation at $28^{\circ} \mathrm{C}$ for 24 $\mathrm{h}$ in the dark, a mycelial disc $(5 \mathrm{~mm}$ in 
diameter) of either 4-day-old $R$. solani AG-4 or $F$. oxysporum f. sp. cyclaminis IHF-1, both collected from colonies on PSA, was placed singly on the center of each Petri dish containing the bacterium. Three replicate plates were used in each assay. Fungal colony diameters were measured after incubation at $25^{\circ} \mathrm{C}$ in the dark for 7 days, and mycelial growth was observed daily under a light microscope.

Biocontrol test. To test the ability of $S$. marcescens $\mathrm{B} 2$ to control damping off caused by $R$. solani, cyclamen seedlings were treated with the bacteria in one of the following two ways: either a $20-\mathrm{ml}$ bacterial suspension (approximately $1 \times 10^{9}$ $\mathrm{CFU} / \mathrm{ml}$ ) was added to the artificial medium in 120 -ml pots containing 2 -week-old seedlings produced as described above, or cyclamen seeds were incubated in the bacterial suspension at $20^{\circ} \mathrm{C}$ for $24 \mathrm{~h}$ on a reciprocal shaker (125 strokes/min) before being germinated as described and grown for 6 to 8 weeks. Two comparison treatments were benomyl, applied in a 100-ppm suspension at $20 \mathrm{ml} /$ pot, or sterile water. Four sclerotia of $R$. solani were buried approximately $1 \mathrm{~cm}$ deep in each pot. All treatment combinations were replicated six times, and placed in a growth chamber at $20^{\circ} \mathrm{C}$, arranged in randomized complete blocks. After 1 week, disease incidence was calculated as the percentage of seedlings damping off.

To test the ability of $S$. marcescens B2 to control wilt caused by $F$. oxysporum f. sp. cyclaminis, the bacterium was applied as a suspension of approximately $1 \times 10^{9}$ $\mathrm{CFU} / \mathrm{ml}$ added to the artificial medium in pots $(15 \mathrm{~cm}$ in diameter) containing cyclamen plants grown as described above. Four comparison treatments were: benomyl, applied in a 100-ppm suspension at $160 \mathrm{ml} /$ pot; $0.2 \%$ colloidal chitin solution, $160 \mathrm{ml} /$ pot; a mixture of $80 \mathrm{ml}$ of bacterial suspension (approximately $2 \times 10^{9}$ $\mathrm{CFU} / \mathrm{ml}$ ) and $80 \mathrm{ml}$ of $0.4 \%$ colloidal chitin suspension; and sterile water. $F$. $o x$ ysporum f. sp. cyclaminis was applied to each pot in $60 \mathrm{ml}$ of a conidial suspension (approximately $1 \times 10^{6}$ conidia $/ \mathrm{ml}$ ). Each treatment combination was replicated three times. The experiment was placed in a greenhouse in a completely randomized arrangement and maintained at 20 to $25^{\circ} \mathrm{C}$ for 3 to 4 weeks until typical wilt symptoms appeared. Disease incidence was evaluated according to a damage index, as follows: $0=$ no yellowing on the leaves, 1 = yellowing of approximately one third of leaves, 2 = yellowing of approximately one half of leaves, and $3=$ yellowing of the whole leaf. Disease incidence (percent) was calculated by the following formula: Disease incidence $(\%)=\left[\left(0 \times \mathrm{n}_{0}+1 \times \mathrm{n}_{1}+\right.\right.$ $\left.\left.2 \times \mathrm{n}_{2}+3 \times \mathrm{n}_{3}\right) / 3 \times\left(\mathrm{n}_{0}+\mathrm{n}_{1}+\mathrm{n}_{2}+\mathrm{n}_{3}\right)\right] \times$ $100\left(\mathrm{n}_{0-3}=\right.$ number of index- 0 to -3 leaves).

Population dynamics of $S$. marcescens $B 2$ in cyclamen rhizosphere. $S$. marcescens B2 was applied to pots containing 6week-old or 10-month-old cyclamen plants in $20 \mathrm{ml}$ of bacterial suspension (approximately $1 \times 10^{9} \mathrm{CFU} / \mathrm{ml}$ ) per $100 \mathrm{~g}$ of artificial medium. Plants were kept in the greenhouse at 15 to $20^{\circ} \mathrm{C}$. Each week after the application, a 1-g sample was taken from each pot at 1 and $5 \mathrm{~cm}$ depth, approximately $2 \mathrm{~cm}$ from the cyclamen tuber, and transferred to a 25-ml bottle. These samples were washed with $10 \mathrm{ml}$ of sterile water, and serial dilutions were cultured on LBCA plates for $24 \mathrm{~h}$. Colonies with reddish pigment and chitinolytic halo were counted to estimate the $S$. marcescens B2 population. Samples were also collected from pots containing a cyclamen seedling grown from seed incubated in the bacterial suspension for $24 \mathrm{~h}$ at $20^{\circ} \mathrm{C}$ ("seed bacterization"), and from pots with no cyclamen plants ("non-rhizosphere").

Chitinolytic and antifungal assays of the culture filtrate. Chitinolytic activity in the culture filtrate of $S$. marcescens B2 was assayed using the following procedure. The bacterium was incubated in liquid LB medium at $28^{\circ} \mathrm{C}$ on a reciprocal shaker (125 strokes/min) for $72 \mathrm{~h}$. The culture was centrifuged at 10,000 rpm for $5 \mathrm{~min}$, and the supernatant was separated into lowand high-molecular-weight fractions with a dialysis tube (12,000-14,000 molecularweight cutoff, 25-mm diameter, regenerated cellulose, Sanko Co., Tokyo, Japan). Fractions were assayed after treatment as follows: heating for $48 \mathrm{~h}$ at 28 or $37^{\circ} \mathrm{C}$, or for $2 \mathrm{~h}$ at $60^{\circ} \mathrm{C}$; autoclaving for $25 \mathrm{~min}$ at $121^{\circ} \mathrm{C}$; or treating with $1 \%$ proteinase $\mathrm{K}$ (EC 3.4.21.14, WAKO Co., Osaka, Japan) for $48 \mathrm{~h}$ at $37^{\circ} \mathrm{C}$. The chitinolytic activity was assayed with $p$-nitrophenyl- $\beta$-D-Nacetylglucosaminide (pNP-NAG1), $p$-nitrophenyl- $\beta$-D-N, $\mathrm{N}^{\prime}$-diacetylchitobiose (pNPNAG2), and $p$-nitrophenyl- $\beta-\mathrm{D}-\mathrm{N}, \mathrm{N}^{\prime}, \mathrm{N}^{\prime \prime}-$ triacetylchitotriose (pNP-NAG3) as substrates. Reaction mixtures containing 100 $\mu \mathrm{l}$ of each fraction diluted 10 times and 10 $\mu \mathrm{g}$ of substrate in $100 \mu \mathrm{l}$ of NcIl vaine buffer, $\mathrm{pH} 6.0$, were incubated at $37^{\circ} \mathrm{C}$ for $60 \mathrm{~min}$. The reaction was stopped with 100 $\mu \mathrm{l}$ of $1 \mathrm{M} \mathrm{Na}_{2} \mathrm{CO}_{3}$ and absorbance of released $p$-nitrophenyl (pNP) was measured at $405 \mathrm{~nm}$ with a spectrophotometer.

The antifungal activity of the fractions was assayed using the following procedure. Sclerotia of $R$. solani AG-4 were incubated in each fraction at $25^{\circ} \mathrm{C}$ for $72 \mathrm{~h}$ on a reciprocal shaker (60 strokes/min). After sterilization of the sclerotia with $70 \%$ ethanol, they were incubated on water agar (WA, $15 \mathrm{~g}$ of agar in 1 liter of distilled water) in a Petri dish at $25^{\circ} \mathrm{C}$ in the dark. Germination of the sclerotia was examined after $48 \mathrm{~h}$ of incubation.

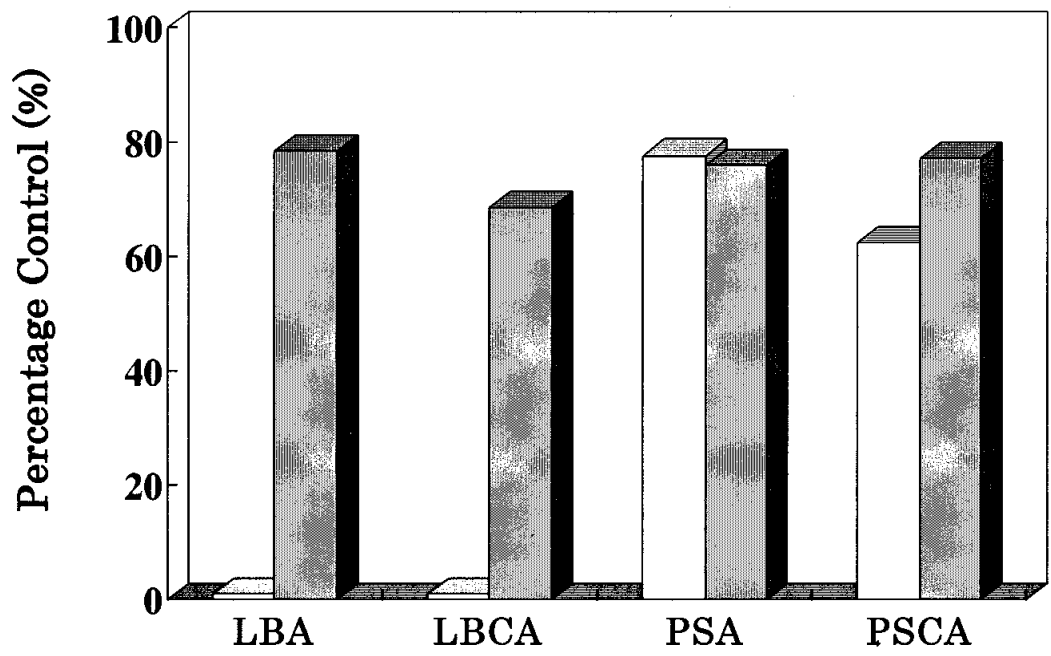

R. solani

F. oxysporum f.sp. cyclaminis

Fig. 1. Radial growth inhibition of Rhizoctonia solani AG-4 and Fusarium oxysporum f. sp. cyclaminis IHF-1 co-cultured with Serratia marcescens strain $\mathrm{B} 2$ at $25^{\circ} \mathrm{C}$ for 7 days in the dark. Fungal growth inhibition was calculated as follows: percent control = (average fungal colony diameter in culture with the bacterium/average colony diameter in culture without the bacterium) $\times 100$. LBA $=10 \mathrm{~g}$ of tryptone, $5 \mathrm{~g}$ of NaCl, $5 \mathrm{~g}$ of yeast, and $15 \mathrm{~g}$ of agar; LBCA $=$ LBA amended with $1.8 \mathrm{~g}$ of colloidal chitin; PSA = potato sucrose agar; and PSCA = PSA amended with $1.8 \mathrm{~g}$ of colloidal chitin/liter. 

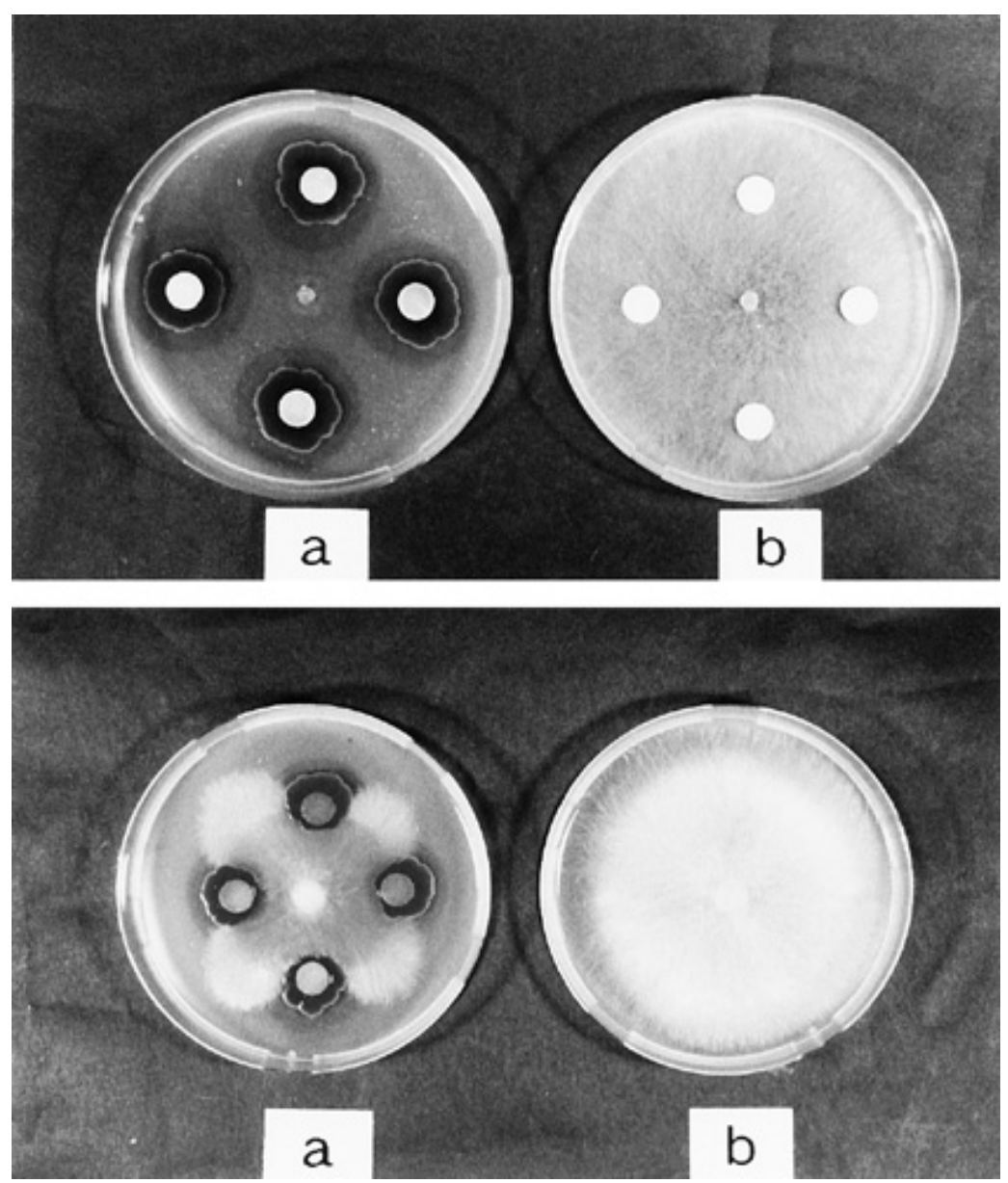

Fig. 2. Radial growth of Rhizoctonia solani AG-4 (upper) and Fusarium oxysporum f. sp. cyclaminis IHF-1 (lower) co-cultured (A) with Serratia marcescens B2 or (B) without the bacterium. The bacterium produced reddish pigment and formed clear zones on LBCA (10 g of tryptone, $5 \mathrm{~g}$ of $\mathrm{NaCl}, 5 \mathrm{~g}$ of yeast, and $15 \mathrm{~g}$ of agar, amended with $1.8 \mathrm{~g}$ of colloidal chitin).
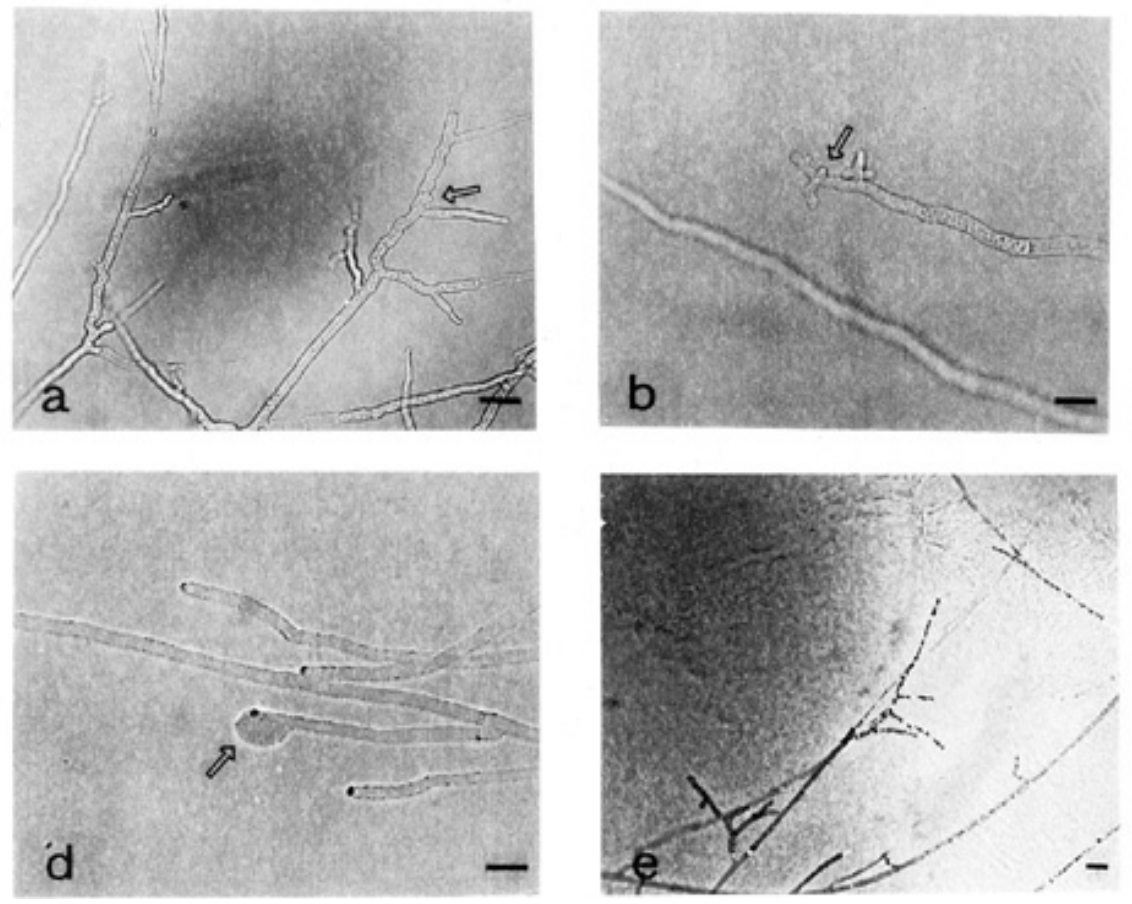

\section{RESULTS}

Growth inhibition of $R$. solani and $\boldsymbol{F}$. oxysporum f. sp. cyclaminis in vitro. Growth of $R$. solani was almost completely inhibited, and growth of $F$. oxysporum f. sp. cyclaminis was reduced to approximately $70 \%$ compared with that in the absence of the bacterial colonies (Figs. 1 and 2). However, the growth inhibition of these fungi by isolate B2 was markedly reduced on PSCA, where neither hydrolyzation of colloidal chitin nor production of reddish pigment by isolate $\mathrm{B} 2$ were detected.

Light microscopy showed abnormal forms of $R$. solani mycelia (e.g., swelling, curling, or bursting), which suggested degradation of the hyphal cell wall or hyphal cell death, on the clear zones around isolate B2 colonies in LBCA (Fig. 3). In F. oxysporum f. sp. cyclaminis mycelia, however, these phenomena were rarely observed.

Suppressive effect of $S$. marcescens B2 on damping off. In a growth chamber, no damping off was observed on cyclamen seedlings in soil treated with either the bacterial suspension or benomyl for up to 5 days after inoculation; whereas, a 33\% incidence of damping off was observed in the control with the pathogen alone (Fig. 4). On the seedlings grown from seed treated with B2, damping-off incidence was $19 \%$, but still lower than in the control. S. marcescens B2 did not cause any significant damage to cyclamen seedlings during the test periods.

Suppressive effect of $S$. marcescens B2 on Fusarium wilt. Under greenhouse conditions, Fusarium wilt incidence was reduced to $55 \%$ on cyclamen plants grown in

Fig. 3. Light microscopy of Rhizoctonia solani mycelia co-cultured with Serratia marcescens B2. The mycelia showed abnormal forms suggesting degradation of the hyphal cell wall: partial swelling (arrows) (A) in the hyphae and (B) at the tip; (C) hyphal curling; (D) burst (arrow) at the hyphal tip; or (E) hyphal collapse. (F) These abnormal forms were not found in mycelia cultured without the bacterium. Scales: $40 \mu \mathrm{m}$. 
soil treated with B2 for up to 21 days after inoculation; whereas, $90 \%$ incidence was observed in the control with the pathogen alone (Fig. 5). In the presence of chitin, the efficacy of B2 increased $20 \%$ over that of treatment with the bacterium alone (Fig. 5). S. marcescens B2 did not cause any significant damage to cyclamen plants during the test periods.

Survival of $S$. marcescens $B 2$ in the cyclamen rhizosphere. In pots with the plants cultivated for 6 weeks and 10 months, the populations of B2 remained near $10^{5}$ and $10^{7} \mathrm{CFU} / \mathrm{g}$, respectively, for more than 12 weeks under greenhouse conditions (Fig. 6). However, B2 was markedly reduced in the unplanted soil, and the bacterium was not detected in the soil at 7 weeks after application. In the soil sown with the seed, the population level remained at $10^{3}$ to $10^{4} \mathrm{CFU} / \mathrm{g}$ for 14 weeks (Fig. 6). S. marcescens B2 and other chitinolytic organisms were not detected in the nontreated control soil.

Chitinolytic and antifungal activities in the $S$. marcescens culture filtrate. After $72 \mathrm{~h}$ in liquid shake culture, the highmolecular-weight fraction of $\mathrm{B} 2$ culture filtrate released pNP from pNP-NAG1, pNP-NAG2, and pNP-NAG3 (Fig. 7). The chitinolytic activity was highest with pNPNAG1. Interestingly, activity with pNPNAG3 was higher than with pNP-NAG2. After heating at more than $60^{\circ} \mathrm{C}$ or treating with proteinase $\mathrm{K}$, the high-molecularweight fraction showed very low chitinolytic activity. Chitinolytic activity was not detected in the low-molecular-weight fraction of B2 culture filtrate (Fig. 7).

When sclerotia of $R$. solani AG-4 were treated with the low- and high-molecularweight fractions of B2 culture filtrate, more than $70 \%$ of the sclerotia failed to germinate on WA plates (Table 1). After sclerotia were heated at up to $60^{\circ} \mathrm{C}$ or treated with proteinase $\mathrm{K}$, the high-molecular-weight fraction showed very low antifungal activity, whereas that of the lowmolecular-weight fraction remained high (Table 1).

\section{DISCUSSION}

Damping off, caused by $R$. solani, is one of the soilborne diseases in cyclamen plants that develops within 10 weeks after sowing. The fungus does not sporulate; thus, the sclerotia are the survival and dissemination units. Sclerotia in soil are very hard to control with fungicides. Also, this fungus can infect an extremely wide range of crop plants. Because of these characteristics, the complete control of this disease with fungicides or the use of resistant cultivars was difficult.

In our experiment, $S$. marcescens B2 survived in the artificial media used for growing cyclamen seedlings under greenhouse conditions. Treatment with the bacterium suppressed damping off in cyclamen seedlings. Also, fungal growth and sclerotial germination were inhibited in the presence of the bacterium in vitro. These results suggested that $S$. marcescens B2 could be used as an effective biocontrol agent against cyclamen damping off under greenhouse conditions.

Fusarium wilt, caused by $F$. oxysporum f. sp. cyclaminis, is also an important soilborne disease of cyclamen plants in Japan. This disease has been controlled with methyl bromide, chloropicrin, or benomyl. These chemicals, however, are undesirable due to sudden reduction of the fungicidal activity, environmental pollution, and cost.

In our biological control test, fungal growth was barely inhibited in the presence of the bacterium in vitro; whereas, bacterial treatment of the soil suppressed Fusarium wilt to $50 \%$ in cyclamen plants. B2 showed no suppression against some isolates of Fusarium, Verticillium, or Gibberella spp. in in vitro tests (21), although Pseudomonas isolates expressing $S$. marcescens chitinase were reported to be

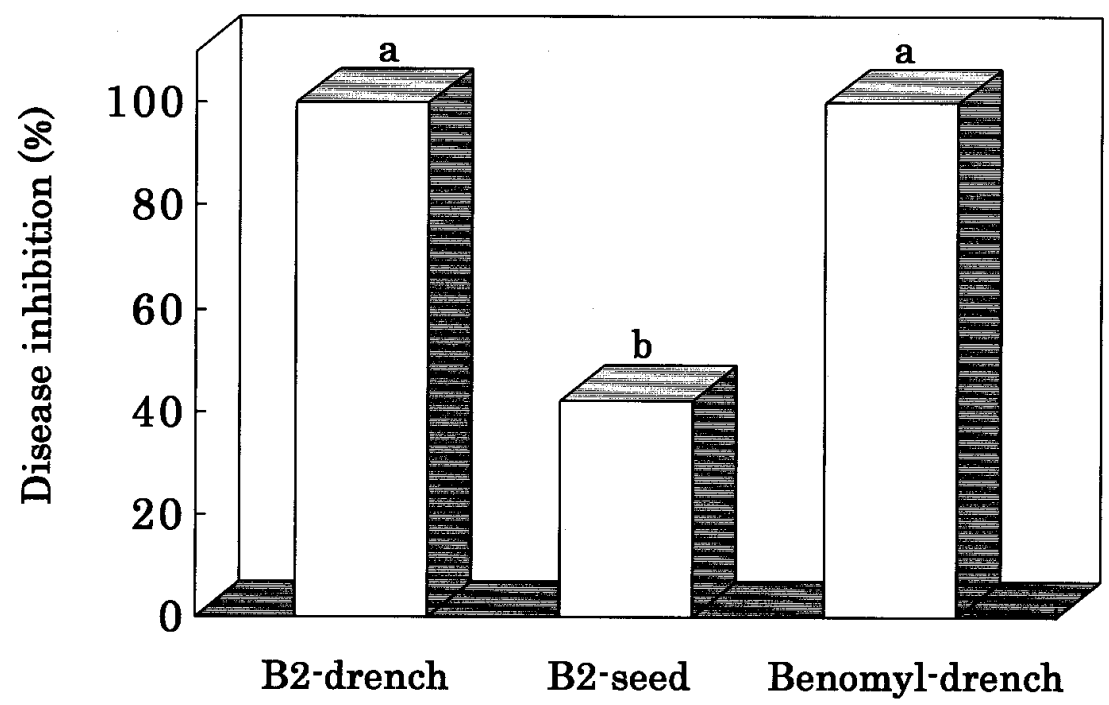

Fig. 4. Effect of Serratia marcescens B2 on Rhizoctonia solani AG-4-induced damping off of cyclamen seedlings. The treatments were as follows: $20-\mathrm{ml}$ bacterial suspension applied to the medium in which seedlings were growing (B2-drench); $100 \mathrm{ppm}$ benomyl applied in a 20-ml suspension (benomyl-drench); or seedlings growing from seed incubated in the bacterial suspension at $20^{\circ} \mathrm{C}$ for $24 \mathrm{~h}$ (B2-seed). Four $R$. solani sclerotia were buried $1 \mathrm{~cm}$ deep in each pot. The disease severity was calculated as the ratio of numbers of seedlings damping off to total number of seedlings 1 week after inoculation. Different letters indicate statistical significance at the $5 \%$ level by Tukey's method.

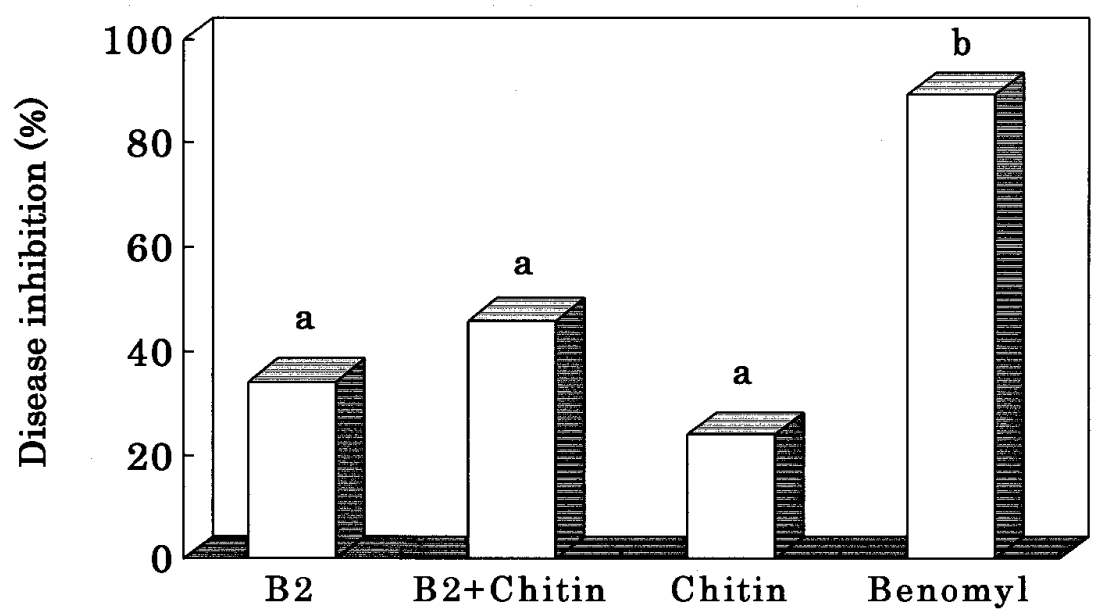

Fig. 5. Effects of Serratia marcescens B2 on Fusarium wilt of cyclamen plants with Fusarium oxysporum f. sp. cyclaminis IHF-1. The treatments were as follows: 160-ml bacterial suspension applied to the medium in which approximately 10-month-old plants were growing (B2-drench); 100 ppm benomyl applied in a 160-ml suspension (benomyl-drench); $0.2 \%$ colloidal chitin solution in a 160-ml suspension (chitin-drench); or mixtures of bacterial suspension and colloidal chitin solution (B2 + chitin-drench). A 60-ml conidial suspension was applied to the medium in each pot. The disease severity was calculated with the following formula: disease incidence $(\%)=\left[\left(0 \times \mathrm{n}_{0}+1 \times \mathrm{n}_{1}+\right.\right.$ $\left.\left.2 \times \mathrm{n}_{2}+3 \times \mathrm{n}_{3}\right) / 3 \times\left(\mathrm{n}_{0}+\mathrm{n}_{1}+\mathrm{n}_{2}+\mathrm{n}_{3}\right)\right] \times 100\left(\mathrm{n}_{0-3}=\right.$ number of index-0 to -3 leaves $)$ at 3 weeks after inoculation. Different letters indicate statistical significance at $5 \%$ level by Tukey's method. 
suitable for biological control of $F$. $o x$ ysporum (17). These results suggested that an indirect effect of B2 was responsible for the inhibition of cyclamen Fusarium wilt rather than a direct antifungal action. Such an idea is supported by reports $(8,9,19,20)$ that systemic resistance against plant diseases was induced in plants by application of plant growth-promoting rhizobacteria, such as $P$. fluorescens.

High antifungal activities were detected in both fractions of $S$. marcescens B2 cul-

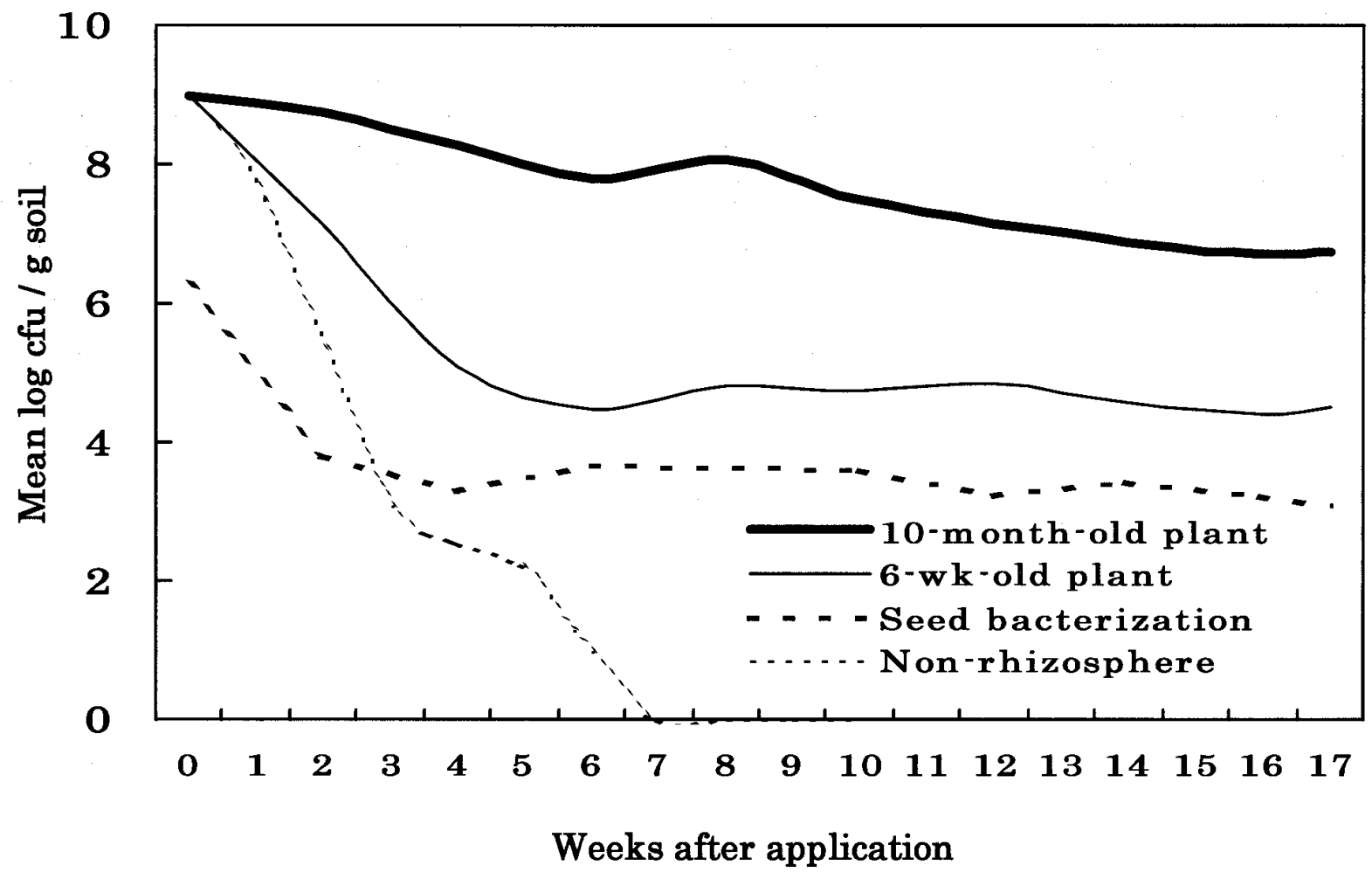

Fig. 6. Population dynamics of Serratia marcescens B2 in pot containing 6-week- or 10-month-old cyclamen plants, a cyclamen seedling from seed incubated in a suspension of $S$. marcescens $\mathrm{B} 2$ at $20^{\circ} \mathrm{C}$ for $24 \mathrm{~h}$ (seed bacterization), or no cyclamen plant (non-rhizosphere).

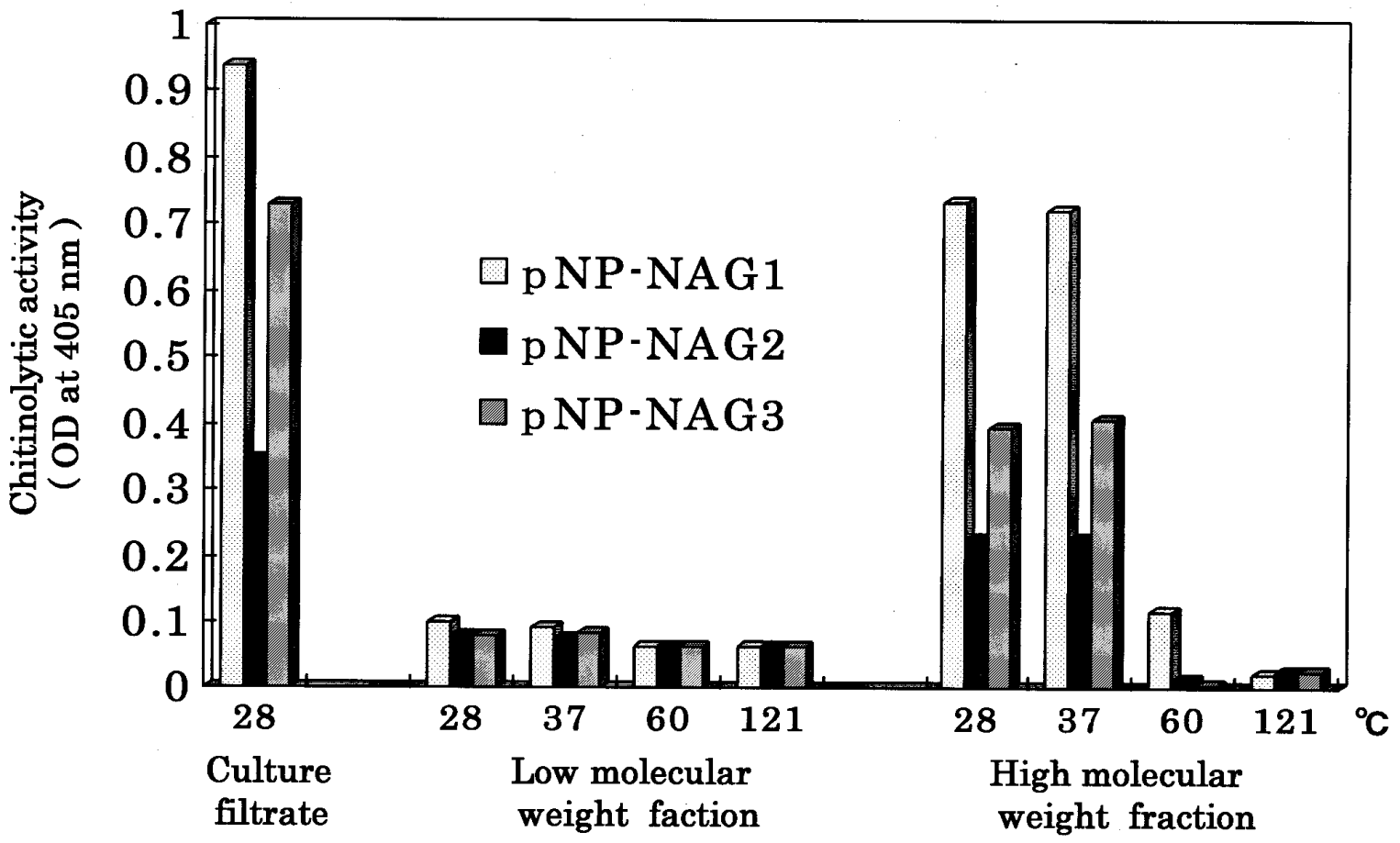

Fig. 7. Chitinolytic activity in low- and high-molecular-weight fractions of Serratia marcescens B 2 culture filtrate. The activity was measured by optical density $\left(405 \mathrm{~nm}\right.$ ) of $p$-nitrophenyl (pNP) released from pNP-NAG1, pNP-NAG2, and pNP-NAG3 after $1 \mathrm{~h}$ of incubation at $37^{\circ} \mathrm{C}$. The fractions were assayed after treatment as follows: heating for $48 \mathrm{~h}$ at $28^{\circ} \mathrm{C}$ or autoclaving for $25 \mathrm{~min}$ at $121^{\circ} \mathrm{C}$. 
ture filtrate; the low-molecular-weight molecule was heat stable and non-proteinaceous, and the high-molecular-weight molecule was heat unstable and proteinaceous. The low-molecular-weight molecule may be the same substance with the reddish pigment, prodigiosin, produced by $S$. marcescens $(12,13)$. This pigment was secreted only at the time when the antifungal activity was detected, and the pigment was fungitoxic to Phytophthora capsci and Pythium aphanidermatum. Both Oomycetes contain little chitin in the cell walls $(1,21)$. Structural analysis of the low-molecular-weight molecule is now in progress.

In our study, activity with pNP-NAG3 was higher than with pNP-NAG2. These results indicate the presence of both exochitinase and endochitinase activities, because exochitinase ( $\mathrm{N}$-acetyl- $\beta$-glucosaminidase) can release $\mathrm{N}$-acetyl-D-glucosamine from the non-reducing end of the chitin chain quite slowly and endochitinases can cut chain oligomers longer than trimer quite rapidly. It is suggested that $S$. marcescens $\mathrm{B} 2$ produced two types of chitinolytic enzymes, endo- and exotypes. These results are compatible with previous reports on the antifungal action of $S$. marcescens and its chitinase toward other fungi $(6,14,16,17)$. In our study, however, although $F$. oxysporum f. sp. cyclaminis was hardly inhibited with $S$. marcescens B2 in vitro, application of the

Table 1. Antifungal activities against Rhizoctonia solani sclerotia by Serratia marcescens strain B2 culture filtrate ${ }^{\mathrm{a}}$

\begin{tabular}{lcc}
\hline $\begin{array}{l}\text { Fraction, } \\
\text { temperature }\left({ }^{\mathbf{C}}\right)^{\mathbf{b}}\end{array}$ & Treatment $^{\mathbf{c}}$ & $\begin{array}{c}\text { Inhibition } \\
(\mathbf{\%})^{\mathbf{d}}\end{array}$ \\
\hline Low & & \\
28 & - & 95.3 \\
37 & - & 93.9 \\
37 & + & 68.3 \\
60 & - & 94.6 \\
121 & - & 83.8 \\
High & & \\
28 & - & 73.3 \\
37 & - & 72.1 \\
37 & + & 14.0 \\
60 & - & 11.6 \\
121 & - & 9.8 \\
\hline
\end{tabular}

a Sclerotia of $R$. solani AG-4 were incubated in each fraction treated (as indicated above) at $24^{\circ} \mathrm{C}$ for $72 \mathrm{~h}$ on a reciprocal shaker $(60$ strokes/min). After sterilization of the sclerotia with $70 \%$ ethanol, they were incubated on water agar at $24^{\circ} \mathrm{C}$ in the dark for $48 \mathrm{~h}$.

${ }^{\mathrm{b}}$ Culture filtrate of $S$. marcescens strain B2 was separated into low- and high-molecularweight fractions with a dialysis tube $(12,000$ to 14,000 molecular weight cutoff, 25 -mm-diameter regenerated cellulose, Sanko Co.). Each fraction was heated for $48 \mathrm{~h}$ at 28 or $37^{\circ} \mathrm{C}$, for $2 \mathrm{~h}$ at $60^{\circ} \mathrm{C}$, or for $25 \mathrm{~min}$ at $121^{\circ} \mathrm{C}$.

${ }^{c}$ Each fraction was treated with $1 \%$ proteinase $\mathrm{K}$ for $48 \mathrm{~h}$ at $37^{\circ} \mathrm{C}$.

${ }^{\mathrm{d}}$ Inhibition of sclerotial germination $=$ ratio of germinated sclerotia to total incubated sclerotia. bacterium as a drench suppressed Fusarium wilt to approximately $50 \%$ in the cyclamen plants. These results suggested that the control of cyclamen Fusarium wilt by the bacteria was by indirect action (e.g., induction of systemic acquired resistance in the plants) rather than direct antifungal action.

Oligosaccharide-elicitors, which are produced by the degradation of the fungal cell wall with chitinase or $\beta$-1,3-glucanase, have been reported to play an important role in signal transduction essential for various plant defense mechanisms (e.g., production of phytoalexins, lignification, and induction of hypersensitive reactions; $2,7,10,18)$. Our results showed that $S$. marcescens B2 secretes both exo- and endochitinase. Also, antifungal substances were detected from the leaves of cyclamen plants treated with isolate B2, but not from untreated cyclamen leaves, by thin-layer chromatography bioassay (data not shown). Based on these facts, we propose that bacterial application to the cyclamen growing medium has an inductive effect on defense reactions but no direct effect on the fungi. This effect is thought to be related to the production of elicitor-like oligosaccharides from the fungal cell walls by hydrolytic action of chitinolytic enzymes of B2. On the other hand, various factors produced by bacterium, $S$. marcescens B2, and Pseudomonas spp. $(11,15)$, have been reported as elicitors inducing systemic resistance to plant diseases. The structural analysis of elicitors produced by $S$. marcescens $\mathrm{B} 2$ is now in progress.

$S$. marcescens $\mathrm{B} 2$ has already been proven useful for biocontrol of gray mold, an airborne disease in cyclamen plants (5). The bacterium produces chitinolytic enzymes, which cause degradation of the fungal cell walls and induction of plant defense reaction, in addition to the antifungal low-molecular-weight molecule. These results suggest that this bacterium may be an effective and persistent biocontrol agent for both airborne and soilborne diseases in cyclamen plants.

\section{ACKNOWLEDGMENTS}

We thank S. Okuyama of the Faculty of Agriculture, Ibaraki University, and K. Tsuchiya of National Institute of Agrobiological Resources, Tsukuba, Japan, for their helpful comments; and E. G. Sudo for English correction

\section{LITERATURE CITED}

1. Akutsu, K., Hirata, H., Yamamoto, M., Hirayae, K., Okuyama, S., and Hibi, T. 1993. Growth inhibition of Botrytis spp. by Serratia marcescens B2 isolated from tomato phylloplane. Ann. Phytopathol. Soc. Jpn. 59:1825 .

2. Dixon, R. A., and Lamb, C. J. 1990. Molecular communication in interactions between plants and microbial pathogens. Ann. Rev. Plant Physiol. Plant Mol. Biol. 41:339-367.

3. Grimont, P. A. D., and Grimont, F. 1981. The genus Serratia. Pages 1187-1203 in: The Prokaryotes: A Handbook on Habitats,
Isolation, and Identification of Bacteria. M. P. Starr, H. Stolp, H. G. Truper, A. Balows, and H. G. Schlegel, eds. Springer-Verlag, Berlin.

4. Iyozumi, H., Akutsu, K., Hirayae, K., Tsuchiya, K., Hibi, T., and Okuyama, S. 1993. Biological control of broad bean chocolate spot disease by Serratia marcescens B2. (Abstr. in Japanese) Ann. Phytopathol. Soc. Jpn. 59:723.

5. Iyozumi, H., Hirayae, K., Komagata, T., Tsuchiya, K., Hibi, T., and Akutsu, K. 1996. Biocontrol of cyclamen gray mould (Botrytis cinerea) by Serratia marcescens B2. Ann. Phytopathol. Soc. Jpn. 62:559-565.

6. Jones, J. D. G., Grady, K. L., Suslow, T. V., and Bedbrook, J. R. 1986. Isolation and characterization of genes encoding two chitinase enzymes from Serratia marcescens. EMBO J. 5:467-473.

7. Lamb, C. J., Lawton, M. A., Dron, M., and Dixon, R. A. 1989. Signals and transduction mechanisms for activation of plant defenses against microbial attack. Cell 56:215-224.

8. Liu, L., Kloepper, J. W., and Tuzun, S. 1995. Induction of systemic resistance in cucumber against Fusarium wilt by plant growth-promoting rhizobacteria. Phytopathology 85:695698.

9. Liu, L., Kloepper, J. W., and Tuzun, S. 1995. Induction of systemic resistance in cucumber against bacterial angular leaf spot by plant growth-promoting rhizobacteria. Phytopathology 85:843-847.

10. Lotan, T., and Fluha, R. 1990. Xylanase, a novel elicitor of pathogenesis-related proteins in tobacco, uses a non-ethylene pathway for induction. Plant Physiol. 93:811-817.

11. Maurhofer, M., Reimmann, C., SchmidliSacherer, P., Heeb, S., and Defago, G. 1998 Salicylic acid biosynthetic genes expressed in Pseudomonas fluorescens strain P3 improve the induction of systemic resistance in tobacco against tobacco necrosis virus. Phytopathology 88:678-684.

12. Okamoto, H., Sato, M., Sato, Z., and Isaka, M. 1998. Biocontrol of Phytophthora capsici by Serratia marcescens F-1-1 and analysis of biocontrol mechanisms using transposon-insertion mutants. Ann. Phytopathol. Soc. Jpn 64:287-293.

13. Okamoto, H., Sato, Z., Sato, M., Koiso, Y Iwasaki, S., and Isaka, M. 1998. Identification of antibiotic red pigments of Serratia marcescens $\mathrm{F}-1-1$, a biocontrol agent of damping off of cucumber, and antimicrobial activity against other plant pathogens. Ann. Phytopathol. Soc. Jpn. 64:294-298.

14. Ordentlich, A., Elad, Y., and Chet, I. 1988 The role of chitinase of Serratia marcescens in biocontrol of Sclerotium rolfsii. Phytopathology 78:84-88.

15. Press, C. M., Wilson, M., Tuzun, S., and Kloepper, J. W. 1997. Salicylic acid produced by Serratia marcescens 90-166 is not the primary determinant of induced systemic resistance in cucumber or tobacco. MPMI 10:761-768.

16. Shapira, R., Ordentlich, A., Chet, I., and Oppenheim, A. B. 1988. Control of plant diseases by chitinase expressed from cloned DNA in Escherichia coli. Phytopathology 79:1246-1249.

17. Sundheim, L., Poplawsky, A. R., and Ellingboe, A. H. 1988. Molecular cloning of two chitinase genes from Serratia marcescens and their expression in Pseudomonas species. Physiol. Mol. Plant Pathol. 33:483-491.

18. Takeuchi, Y., Yoshikawa, M., Takeba, G., Tanaka, K., Shibata, D., and Horino, O. 1990. Molecular cloning and ethylene induction of mRNA encoding a phytoalexin elicitor-releasing factor, $\beta$-1,3-glucanase, in soybean. 
Plant Physiol. 93:673-682.

19. Wei, G., Kloepper, J. W., and Tuzun, S. 1991. Induction of systemic resistance of cucumber to Colletotrichum orbiculare by select strains of plant growth-promoting rhizobacteria. Phytopathology 81:1508-1512.
20. Wei, G., Kloepper, J. W., and Tuzun, S. 1996. Induced systemic resistance to cucumber diseases and increased plant growth-promoting rhizobacteria under field conditions. Phytopathology 86:221-224.

21. Yamamoto, M., Iyozumi, H., Akutsu, K.,
Hirayae, K., Hibi, T., and Okuyama, S. 1992. Suppressive effects by Serratia marcescens B2 against Botrytis fabae induced chocolate spot disease of broad bean. (Abstr. in Japanese) Ann. Phytopathol. Soc. Jpn. 58:582583. 